\title{
MANAGING CUSTOMER LOYALTY IN THE AUTOMOTIVE INDUSTRY USING SIX SIGMA AND "THE TOYOTA WAY" METHODOLOGY
}

\author{
Ilija Popjanev \\ D0OR Training, Skopje, Republic of Macedonia
}

\author{
CMESTE NGO \\ JEL Category: M11
}

\begin{abstract}
In times of economic crisis and dropped sales, automotive manufacturers spending their resources wisely and focus on areas with bottom-line impact. Such a focus is the customer loyalty, which is a "must" for automakers that compete in present environment. The average replacement cycle for auto buyers is usually three or four years...or even longer, unlike other consumer products with more frequent replacement cycles. Therefore, loyalty needs to be in the focus of automotive manufacturers and help building customer retention.
\end{abstract}

While many automotive manufacturers have started customer satisfaction programs, most of them don't realize that the customer train has left the station without them. Here are some facts on the negative influence of customer satisfaction. More than 90 percent of the Fortune 200 companies are convinced that maximizing customer satisfaction maximizes profitability and market share. Yet fewer than 2 percent are able to measure bottom-line improvements from documented increases in levels of customer satisfaction. There are 15 to 40 percent of customers who say that they are satisfied defect from a company each year. In the European auto industry, the average repurchase rate of satisfied customers from the same car company is less than 30 percent. The corresponding figure for the appliance industry is below 45 percent. The defection rate of people over age 65 is 40 percent; for those over age 35 it is 60 percent; for those between ages 20 to 35 it is more than 85 percent.

Keywords: research, customer, loyalty, retention, satisfaction, process, deflection, Six Sigma, DMAIC

\section{RESEARCH METHODOLOGY}

This research is made for the purposes of the dealership Auto House Skopje, a GM - Opel and Chevrolet dealership in Macedonia, analyzing customer loyalty for a period of 10 years, but an impact is made for the whole automotive industry in Macedonia, Europe, USA and Asian models.

\footnotetext{
Adresa autora:

Ilija Popjanev

邦: ilco@doortraining.mk
}

Six Sigma is a disciplined approach to improving product, process and service quality. Since its inception at Motorola in the 80'es, Six Sigma has evolved significantly and continues to expand to improve process performance, enhance business profitability and increase customer satisfaction.

This research presents experiences of practitioners on Six Sigma, followed by the application of the Define, Measure, Analyze, Improve, and Control (DMAIC) problem-solving methodology to identify the parameters causing casting defects and to control these parameters. The results of the study are based on the 
application of tools and techniques in the DMAIC methodology, i.e. Pareto Analysis, Measurement System Analysis, Regression Analysis and Design of Experiment. (Jiju, 2007) The results of this research show that the application of the Six Sigma methodology increase customer loyalty and customer retention.

In the Toyota Way, it's the people who bring the system to life: working, communicating, resolving issues, and growing together. (Liker \& Meier, 2006) The Toyota Way goes well beyond this; it encourages, supports, and in fact demands employee involvement. It's a culture, more than a set of efficiency and improvement techniques. The employees will reduce inventory, identify hidden problems, and fix them. The employees have a sense of urgency, purpose, and team work because if they don't fix it there will be an inventory outage. This effort requires a combination of committed management, proper training, and a culture that makes sustaining improvement a habitual behavior from the shop floor to management.

How managers can dramatically improve their business process and improve to customer loyalty and increase retention using Six Sigma and The Toyota system: eliminating wasted time and process, building quality into workplace systems, finding low-cost but reliable alternatives to expensive new technology and perfecting business processes, all in purpose increasing customer loyalty, customer retention and satisfaction.

\section{INTRODUCTION}

Currently, companies are in increasingly competitive environment in which customer's satisfaction and loyalty are vital factors in the success of any organization. This requires the use of continuous improvement methodologies, such as Six Sigma, which enable companies to improve customer satisfaction and meet their expectations. (George, Rowlands, Price, \& Maxey, 2005)

This research describes a case study carried out in a company from the automotive industry that has selected a Six Sigma project to respond to increasing in customer loyalty above customer satisfaction and buildup retention. The objective of the project was to improve the process of analysis of customer behavior through the identification of the variables that influence the customer behavior concerning loyalty and satisfaction and proposes several improvements and eliminate potential hazards and bad influences. Results are positive and can encourage managers from other industry sectors or even services to improve their customer loyalty and customer retention handling process using Six Sigma methodology.

Empirical evidence suggest that it costs significantly less to retain an existing customer than to acquire a new one, making loyalty very important in times when marketing budgets are decreased. While customer retention is necessary to maintain market share and sales volumes, loyalty alone won't grow these figures. Now the OEM's need to find the balance for spending money and resources to customer loyalty vs customer acquisition.

Clearly, there is little correlation between customer satisfaction and customer loyalty.

By contrast, here are the facts on the enormous positives of customer loyalty:

Fact 1 - There is a very close correlation between customer loyalty and profitability.

Fact 2 - A 5\% reduction in customer defection can result in profit increases from $30 \%$ to $85 \%$

Fact 3 - If customers increase their customer retention by $2 \%$, it is the equivalent of cutting their operating costs by $10 \%$.

Fact 4 - Loyal customers provide higher profits, more repeat business, higher market share, and more referrals than do "just satisfied" customers.

Fact 5 - It costs five to seven times more to find new customers than to retain customers.

Fact 6 - One lifetime customer is worth more than 500,000 EUR to a car company

There are shining examples of companies that have put customer loyalty on a pedestal and as a result have an amazing financial success. Each of them exceeds 95 percent customer retention per year. They include John Deere, Lexus, among others.

For any company, large or small, the emphasis must be on the practical and the doable, and there are several essential topics or principles noted in this research:

1. Measure the Right Repurchase Behaviors

2. Highlights evolving changes in owner loyalty trends

3. Reduction of the Customer Base and Differentiation

4. Measurement/Quantification of Core Customer Defections

5. Make Owner Loyalty a Cross Functional Focus 
6. "Taking the Customer's Skin Temperature Every Day"

7. Assessment of Customer "Wow!"

8. Establishment of the Company Infrastructure for Customer Loyalty

9. Understand (and Act on) Key Drivers of Loyalty

\section{MEASURE THE RIGHT REPURCHASE BEHAVIORS}

It's a cliché, but it's true: you can't manage or improve what you don't measure. The first step in building and maintaining owner loyalty is to ensure that you have an accurate approach to measuring it. A holistic household approach is recommended to track owner loyalty since, unlike other approaches, this method captures both vehicle disposal and fleet additions made by consumers.

Once a measurement system is in place, an organization should establish a baseline measurement of owner loyalty. From there, automakers have the foundation to track and trend loyalty over time and assess the impact of communications, incentives and other aspects of the owner experience on loyalty. It is important to avoid using campaign-specific metrics as a proxy for the company's overall loyalty score. While these are often more accessible due to the prevalence of marketing campaigns, these "micro-loyalty metrics" do not take a comprehensive view of all efforts exhibited by the automaker and its dealer network.

In the auto industry, customer satisfaction and loyalty are sometimes confused with each other. While customer satisfaction is an important metric, it is a means to an end, not a desired end result. Therefore, the industry should challenge dealer incentives paid for high satisfaction. After all, a customer may rate the experience as "highly satisfactory" but not go on to buy another vehicle from the manufacturer next time. Satisfaction, especially when it is self-reported, is not a reliable indicator of repurchase.

We have observed a positive trend in the industry: an increasing number of our clients are using dealer loyalty scorecards as a factor in determining dealer compensation. Since loyalty is a strategic and long term goal, we feel that compensating dealership personnel based on consumer loyalty will yield far better results than paying for customer satisfaction.

Loyalty is especially important today with certain auto brands disappearing (e.g., SAAB, Rover, Hammer, Pontiac, Saturn), the imminent threat of these owners abandoning a corporate portfolio is high. My research found a steady decline of corporate loyalty among Chevrolet owners once the decision was announced in autumn 2013 that this GM brand will stop sales in EU countries effective from year 2015. This trend shows the timely importance of building and creating loyalty to the manufacturer when confronted with losses to rival brands. In the case of Saturn, owner defections were wins for Toyota and Honda. In the case of Chevrolet the winners probably will be the Asian brands like Kia, Hyundai etc.

\section{HIGHLIGHTS EVOLVING CHANGES IN OWNER LOYALTY TRENDS}

As shown in Figure 1, make and corporate loyalty for the industry was fairly consistent from 2001 to 2008. Even as US sales were shrinking from 17.4 million in 2001 to 13.2 million in 2008, automakers and brands were able to maintain a fairly consistent level of repeat sales with their customers. On the other hand, you will agree that automotive manufacturers missed an opportunity to increase loyalty at a time when sales were shrinking and the retention of each customer assumed critical importance. Some makes and corporations have been able to achieve aboveaverage levels of loyalty. For example, owner loyalty to Toyota Motor Sales has grown as the manufacturer has increased its share of the US

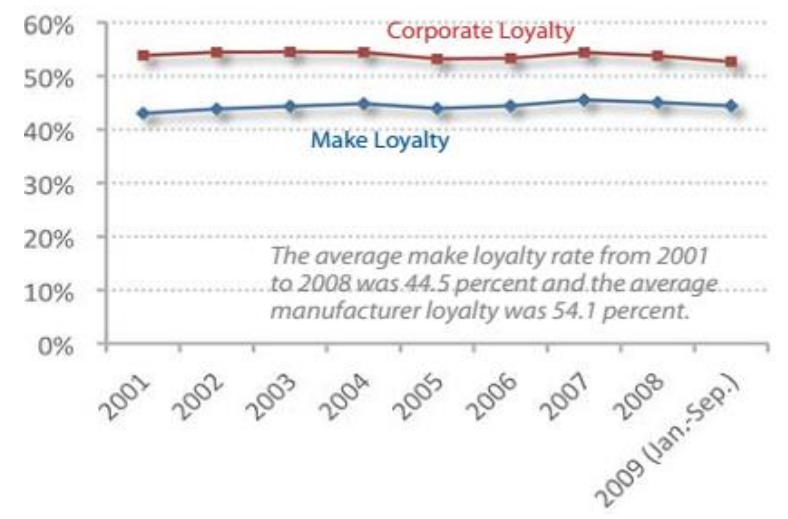

Fig. 1 Industry average make and corporate loyalty

Source: (Zetu \& Miller, 2010) 
retail market. In fact, the 2009 model year represents the first time since I started measuring manufacturer loyalty that Toyota has surpassed General Motors, reflecting the momentum Toyota has achieved among its customer base.

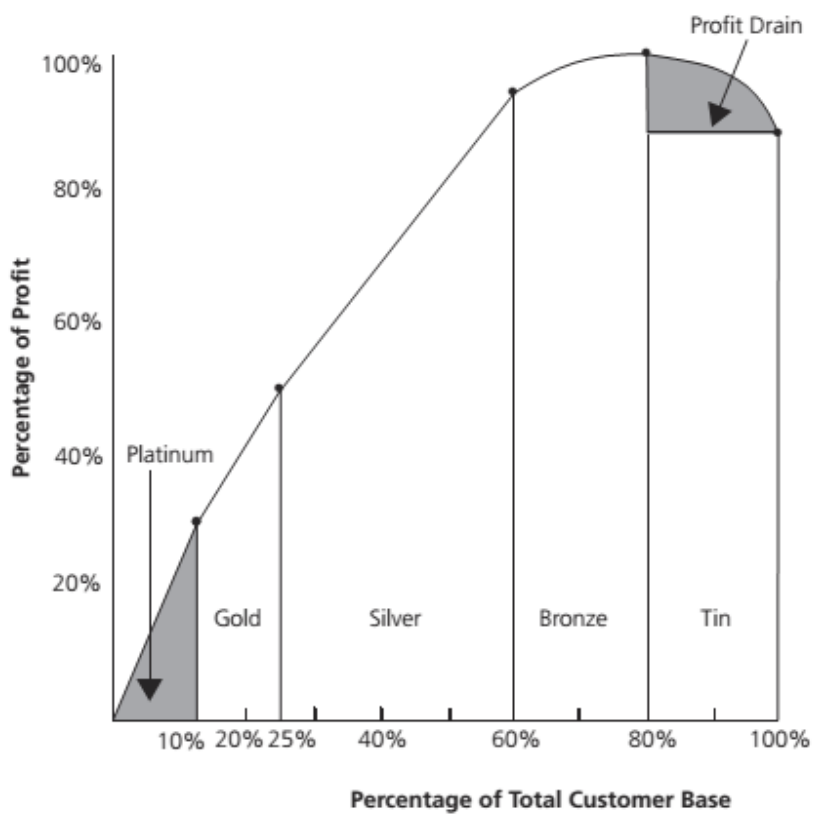

Fig. 2 Platinum, gold, silver, bronze, and tin customers: their differentiation and contribution to profitability

Source: (Bhote, 2003)

The month-long "Cash for Clunkers" incentive, which ran from late July to late August 2009, had a positive effect on industry sales. Under this program, August auto sales for the US exceeded one million units, the first time monthly sales exceeded one million in over a year. However, the effect on loyalty was profoundly negative, showing that consumers can sometimes be incented by generous discounts to switch from one vehicle, brand or manufacturer to another. During this incentive program, some manufacturers saw their corporate loyalty rates fall by as much as 13 percentage points in one month. These statistics indicate that loyalty can be "bought," although some experts might argue that loyalty that can be purchased is not true loyalty.

Loyalty can be measured at different levels: to the model, to the make (i.e., brand) and to the manufacturer. For purposes of this research, loyalty is measured on a scale of 0 to $100 \%$ and reflects the proportion of owners who return to the market to acquire another vehicle of the same model, make or knowing that customers can be fickle, what can automakers do to manage and build owner loyalty?

\section{REDUCTION OF THE CUSTOMER BASE AND DIFFERENTIATION}

The traditional approach means: "The more customers, the better." Growth becomes a mantra.

The Ultimate Six Sigma Discipline means. "Not all customers are worth keeping, just as not all suppliers, distributors, or product lines are worth keeping."

During a consultation with a company that was losing money, we asked the CEO how many of his 800 customers were profitable. "About 200," he replied. "Then why do you keep most of the rest?" His straight-faced answer: "To keep the plant busy!"

Unless a company is in the charity business for its customers, the indiscriminate pursuit of all customers is plain dumb.

Figure 2 illustrates a metal analogy to differentiate and segment a customer base into four categories:

- Platinum customers constitute $10 \%$ of the total customer volume of a company but constitute $30 \%$ of its profit. They are the most loyal of customers and the most difficult for competition to steal.

- Gold customers span $15 \%$ of the company's customer volume and provide $20 \%$ of its profits. They are almost as important as the platinum customers, but are not part of the strategic alliances. Together, the platinum and gold customers are labeled core customers who require continuous, never-ending attention and care.

- Silver customers account for $35 \%$ of the customer base and about $40 \%$ of the company's profits. Maintain relationships with these customers, but there is no need for assiduous cultivation.

- Bronze customers number $20 \%$ by customer volume but barely $5 \%$ of the company's profits. For these customers, the company is on a slippery slope from black ink to red ink. Be prepared to cut loose from them.

- Tin customers total $20 \%$ by customer volume and actually drain profits by $15 \%$. Dump them. (Often, sentimental ties or the future potential 
of converting them into profitable customers may hold a company back from terminating them. At the very least, an attempt should be made to increase prices to facilitate their exit or enhance profitability.)

It is estimated that a customer base reduction of $30-40 \%$ can be accompanied by a $20-30 \%$ improvement in profits. defector has forty years of adult life left; that the average cost of the car is $€ 20,000$; and that the customer will buy ten such cars in his working life. $\mathrm{He}$ is likely to tell twenty of his friends and relatives about his unhappiness with the company. Assume that three of the twenty people he tells heed his advice and won't buy another car from the company, either!

The loss to the company, therefore, is not $€ 30,000$

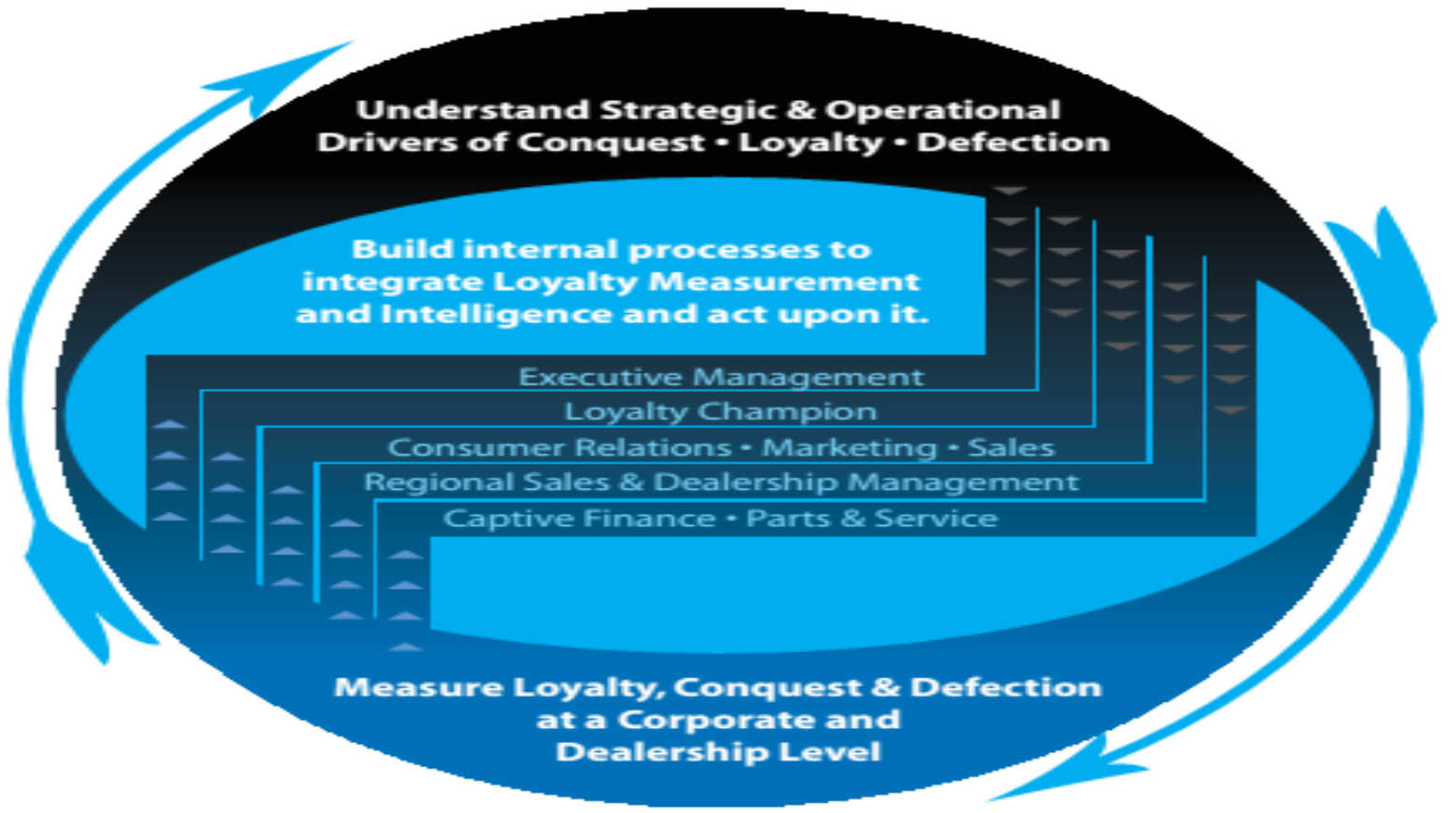

Fig. 3 Loyalty, conquest, and defection relationship

\section{QUANTIFICATION OF CORE CUSTOMER DEFECTIONS}

The traditional approach means: "More than 99 percent of companies do not measure the cost impact of the defection of their core customers." Even worse, their accounting departments, which continue to live in the nineteenth century, do not even know how to estimate the financial loss from such defections. The stark result is that these companies miss the boat on the most prolific technique, bar none, to improve their profits.

The Ultimate Six Sigma Discipline means: "Contrary to the conventional wisdom, customer defection is actually easy to quantify. The loss need not be 100 percent accurate with accounting certitude."

What is the cost to a car company of a single defector who is so turned off that he will never buy from that company again? Assume that the but $10 \times € 20,000 \times 3$ - or $€ 600,000$. Add the loss of servicing, parts, and financing and the costs may exceed $€ 1$ million.

The previous example can be replicated for any company, any industry. The numbers may not pass a strict accounting muster, but the multiplier effect of the loss of a single core customer cannot be denied. It must be measured. It must be quantified.

With a typical customer defection rate of 15 percent to 40 percent, the potential loss of such defections run into millions for a large company.

It is for this reason that warranty costs are just the tip of the huge iceberg of profit loss. The cost of a potential defecting customer is often at least hundred times the paid out costs of a warranty claim. 


\section{MAKE OWNER LOYALTY CROSS FUNCTIONAL FOCUS}

As sales have dropped for nearly every automaker, senior leadership has begun to focus on maintaining current customer assets. Manufacturers and dealers are finally starting to realize that loyalty is not just a metric that measures the success of a single marketing campaign.

Experience tells us that manufacturers are most successful at building and maintaining loyalty when multiple parts of the organization are focused on customer retention. Also, dealers tend to take loyalty much more seriously when it's a cross functional corporate focus that is endorsed by senior leadership. Beyond the traditional brand and marketing management owners, automakers should involve these parts of the organization:

- Captive finance - The lease termination process is a classic example of a part of the ownership experience that can be used to improve loyalty. Many times, customers are negatively surprised near the end of their lease term when they find out that they were paying only interest in the first year or they will be penalized if they don't invest in vehicle repairs before the end of leasing period. Therefore, the lease-end process often has a negative effect on the impression that customers have of the dealership and the automaker in their final days of owning a product.

Our client engagements identified an opportunity for front-line call center staff to more proactively talk to customers and make sure that requirements for receiving their lease deposit are understood earlier in the process. This investment in communication and training leads to a more favorable impression of the lease turn-in process, and can result in higher repurchase of an automaker's product.

- Certified pre-owned/certified used - In most cases, the primary objective of CPO operations is to convert used buyers into new vehicle buyers. Therefore, OEMs should track the experience of buying a CPO unit to understand what drives loyalty, and what will result in an up sell to a new vehicle.
- Dealer training/regional field staff - I mention before, manufacturer field staff are increasingly relying on dealer loyalty scorecards to help coach dealers on how to keep current customers. A customer's experience with any brand or specific vehicle starts with a dealership; therefore, improvement objectives should be established at the retail level. Based on my experience in designing and delivering dealer loyalty programs, l've observed that dealer buy-in into these programs is critical. Unless dealers support the loyalty program, field and corporate personnel will have a very tough time getting scores and improvement plans embraced by the dealer management.

- Parts \& Service (P\&S) - We continue to see significant gaps in the strategic collaboration between staff managing $P \& S$ and new vehicle sales operations. This is a huge mistake, as good service can drive new sales and contribute to owner loyalty. In one case for European OEM, the loyalty to the company was twice as high among customers having service done by the franchised dealer network than for owners not visiting the dealer network for customer pay services.

In prior client discussions, I was surprised to hear that some in the industry don't agree that sales and service business unit objectives need to be aligned and that there seems to be a lack of understanding of the fixed operations factors that drive new vehicle sales.

Also, analysis of repair order data, which appears to be underutilized based on regular discussions with our client base, reveals that service incentives may be a worthwhile investment in repurchase loyalty. For one automaker, every euro that the dealer or manufacturer spent on service incentives had the potential to increase customer loyalty by $0.45 \%$ points, which equates to $€ 575,000$ in additional profits on 338 extra new vehicles sold.

Product Planning/Product Development - What does a major launch, product refresh or product enhancement have to do with owner loyalty? Answers to this question should provide direct input to product planners who support goals held by vehicle line executives or other brand managers. My customer analysis was based on 12 
different models showed that, on average, model loyalty increased by $24 \%$ after a major product redesign. And, the positive impact on loyalty lasts approximately 15 months after the quarter during which the redesign was launched. These results show that product development or product planners should have input to cross-functional loyalty teams so they understand which product attributes may influence repeat sales.

\section{8 “TAKING THE CUSTOMER'S SKIN TEMPERATURE EVERY DAY"}

Traditional Approach. There are undoubtedly companies that believe that this would be a better world if there were no customers! But even good companies do not cultivate customers. Close personal relationships are rare. Top management visits to customers are rarer still, and after the sale is made the customer is relegated to history.

By contrast, in the Ultimate Six Sigma, the relationship is guided by the famous founder of the Matsushita empire, Konosuke Matsushita, who insisted that his sales force "take the customer's skin temperature every day!" This entails:

- Creating a firm win-win partnership with core customers, based on ethics, mutual trust, and mutual help

- Keeping a finger on the pulse of every core customer-his requirements, hopes, concerns, and irritations-not once, and not through a routine survey or associated statistics, but in a continuum of time

- Building close personal relationships and bridges with key customer personnel, not in a fawning manner, but in terms of building a ladder of mutual trust

- Having top management visit customers to get firsthand and direct feedback without the distorting filter of a protective bureaucracy.

- Never forgetting about the customer after the sale is consummated. It costs five to seven times more to find new customers than to retain present customers. Even if future sales are not generated, these customers can be an invaluable source of referrals and word-ofmouth advertising.

Bob Galvin, Motorola's retired chairman, would visit each of his top-ten customers, spending a whole day not with his counterpart CEOs, but with the troops that were the real users of Motorola products. One of the key points they stressed was that Motorola was good at telling customers what they needed, but poor at listening to what they wanted. As a result, each Motorola executive is now required to meet regularly with ten of his top customers-an invaluable source of customer input. (Bhote, 2003)

A survey looked into why customers don't go back to the same dealer that they bought their last car from. The survey revealed that: one percent had died; 3 percent had moved to another town; 5 percent shifted because of price; 9 percent bought another car brand; 14 percent switched because of poor service. What happened to the remaining 68 percent? They switched because "the dealer didn't give a damn after the sale!"

\section{ASSESSMENT OF CUSTOMER "WOW!"}

The traditional approach means: "In assessing what the customer wants, it is not the voice of the customer that is heard, but the voice of the engineer who thinks he knows more about the customer's needs than the customer."

The Ultimate Six Sigma Discipline means: "Two disciplines are used to capture the voice of the customer - mass customization and quality function deployment."

Briefly, mass customization recognizes that each customer is unique and has highly individualized requirements. Each customer today wants exactly what he wants, where he wants it, when he wants it, at the price he wants. It turns topsy-turvy Henry

Ford's famous choice of "any color you want as long as it is black!"

Quality function deployment (QFD) is more suited when there are a large number of core customers with common requirements. The specific discipline is the House of Quality, where customer attributes and competitor perceptions are translated into engineering specifications. If done correctly, QFD can perform a new design in half the time, at half the cost, with half the defects and half the manpower required in older designs. After ten years, however, the bloom is off the QFD rose because of the lower and lower commonality of customers and their higher and higher individualization. 
Concentration on All Elements of Customer "Wow" Traditional approaches focus on performance and/or quality as customer priorities. However, there are twenty characteristics of a product or service that are of interest to customers. For products, Figure 4 depicts a network of elements that combine to create "wow" in the customer's mind. Two factors are most important to customer "wow." First, the design should introduce features unanticipated by the customer, but whose creation results in a rush of customer delight. The second states: "It is that element missing from a product

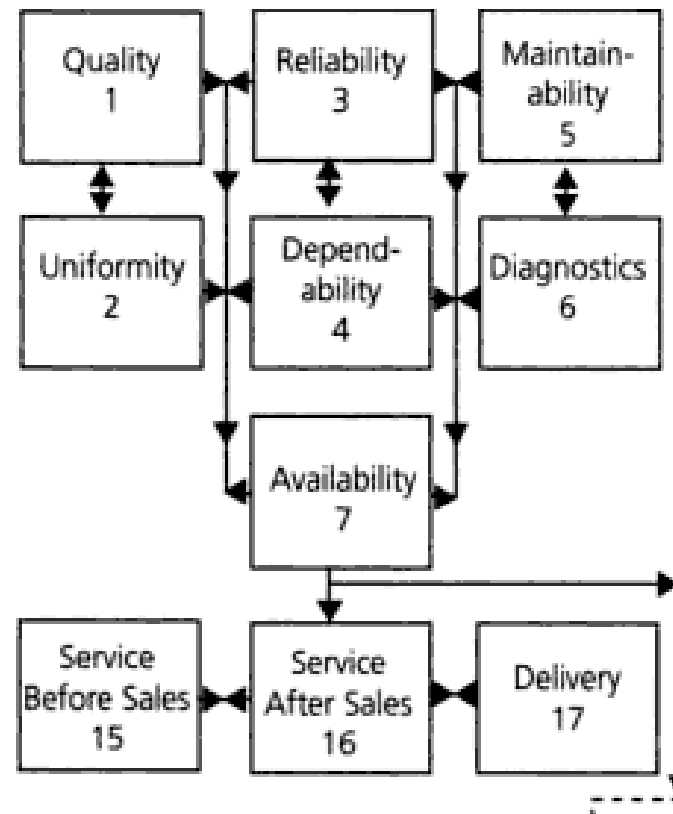

1. Quality: Toward Zero Defects

2. Uniformity: Toward Zero Variation

3. Reliability: Toward Zero Field Failures

4. Dependability: Toward Lifetime Guarantees

5. Maintainability: Toward Accurate, Fast, Low-Cost Repair

6. Diagnostics: Toward Customer Self-Diagnostics

7. Availability: Toward $100 \%$ Uptime

8. Technical Performance: State-of-the-Art Technology

9. Ergonomics: Styling, Color, Ease of Operation"User Friendly"

10. Core Features: Expected by Customer

11. Delight Features: Unexpected Features That Thrill Customer

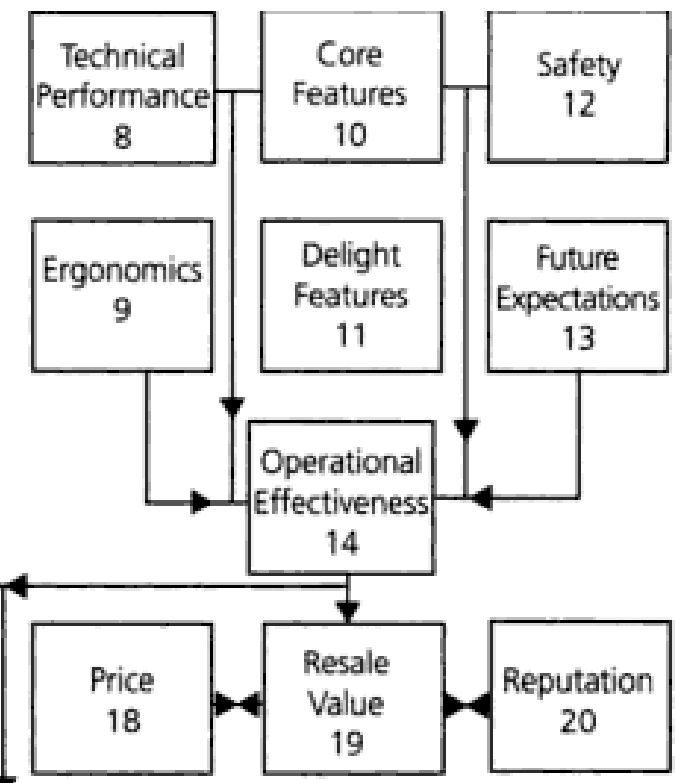

or service which is important to a customer that a company must pursue with laser like precision and intensity." With the constant desire for quantification and a scoring system, on the one hand, and a complex array of parameters to assess performance on the other, how can a single numeric score say, from 1 to 100 points, be assigned to subjective evaluations of companies by core customers, or of company leadership by its employees, or of internal suppliers by internal customers within a company?
Customer "WOW" 21
12. Safety: Of Product and to User Product Liability Prevention
13. Future Expectations: Anticipating Needs
14. Operational Effectiveness: Integration of Boxes 8 through 13
15. Service Before Sales: Sales, Coopera- tiveness, Communication
16. Service After Sales: Sustained Contact and Interest After Sales
17. Delivery: Short Cycle Time
18. Price: Cost Below Competition
19. Resale Value: High Percent of Purchase Price: Cost Below Competition
20. Reputation: Image, Perceived Quality
21. Customer "WOW": Value, Delight, Loyalty

Fig. 4 A network of elements of customer "wow" for products

Source: (Bhote, 2003)

The same principles and type of index can be used for any subjective evaluation, such as leadership and for the service industry, support services in the manufacturing industry, and internal customer/supplier links. The elegance of the company effectiveness index is the remarkable way in which it simultaneously analyzes:

- The relative importance customers attach to their priority requirements 
- The strength and weakness of the company for each requirement as determined by the customer

- The strength and weakness of the company for each requirement vs best competitor, again as determined by the customer

\section{ESTABLISHMENT OF THE COMPANY INFRASTRUCTURE FOR CUSTOMER LOYALTY}

Traditional Approach. Since most companies are not even aware that customer loyalty is such a prolific profit generator, they have no organizational structure to address it. In fact, a survey conducted by the CMS Consultancy Group on customer retention revealed these shocking findings:

- Sixty-one percent of companies surveyed felt that customer defections would have an insignificant impact on sales.

- Over 33 percent made no attempt to identify defecting customers.

- Twenty-five percent did not ask defecting customers their reasons for leaving.

- Thirty-three percent took no action on defecting customers.

The Ultimate Six Sigma Discipline. In order to sustain a customer loyalty culture, it is necessary to build a viable company infrastructure: This requires four disciplines meaningful metrics, a toplevel steering committee, a chief customer officer, and a customer defection management SWAT team.

Metrics are the essential starting point to establish a customer loyalty baseline. Among the most important are:

- Reduction of total customer base (with retention of primarily platinum and gold customers)

- Defection rate (i.e., defecting customers as a percent of the total number of customers)

- Amount and continuity of core customers (e.g., by number, by dollars, by time)

- Repeat purchases by core customers

- Referrals by core customers

- Correlation of customer retention and profitability
There is no business purpose more important than customers and no parameter more profitable than customer loyalty. This makes a top management steering committee essential. It should consist of the CEO as chairman and his direct reports as members. The steering committee's tasks include:

- Establishing targets for minimum retention rates and longevity of core customers

- Appointing a customer czar and a customer defection SWAT team

- Reviewing progress against targets

- Tying senior management incentives to increasing retention rates

- Promoting synergy between the customer, employees, and the supply chain

\section{TO UNDERSTAND (AND ACT ON) KEY DRIVERS OF LOYALTY- RESEARCH CONCLUSION}

Understanding that customer loyalty is important (and organizing staff around this objective) is the first step; knowing what to do to build and maintain it is the critical second step.

A number of factors, including product attributes, customer relations and financial issues, affect customer loyalty. Which of these drivers of repurchase are most important to customers? Where should OEMs focus their efforts to improve customer loyalty and stop defection to the competition? In 2009, I made an analysis to determine how customer perception with a number of product-related, customer relations and monetary factors shown in Figure 5 affects repurchase intent, a proxy for loyalty. I looked at which factors were most important in driving loyalty for automotive consumers overall, as well as for two sub-groups: luxury vs. non-luxury vehicle owners and vehicle owners by brand origin (Asian, USA and European).

To quantify the impact of each factor on customer loyalty, I looked at how an increase of 5 percent in favorable customer perception of a specific factor, e.g., fuel economy, would positively affect repurchase intent. The findings of this study provide strategic input for sales, marketing and communication strategies geared toward creating and maintaining loyalty based on what is most important to specific customer groups. Product Quality, Fuel Economy and the Customer Experience Are Consumer "Hot Buttons". My 
Popjanev I. Managing customer loyalty in automotive industry

MEST Journal Vol. 4 No. 1 pp. 99-110

analysis showed that the number one driver of

perception of the vehicle's quality would result in a consumer repurchase is perception of product 1 percentage point increase in repurchase intent, quality. A 5 percent improvement in customer the highest of any measured loyalty driver.

\begin{tabular}{|l|l|l|}
\hline Product-Related & Customer Relations & Financial \\
\hline - Product Quality & - Sales Process & - Purchase Price \\
- Quality of Workmanship & - Communications & - Availability of Incentives \\
- Fuel Economy & - Maintenance Service at & - Finance Options \\
- Safety & Dealership (where applicable) & - Monthly Payment (where \\
- Comfort \& Convenience & & $\begin{array}{l}\text { applicable) } \\
\text { - Performance }\end{array}$ \\
- Ride \& Handling & & $\begin{array}{l}\text { Cost of Ownership (not including } \\
\text { monthly payment) }\end{array}$ \\
\hline
\end{tabular}

Fig. 5 Factors affecting loyalty

Source: (Zetu \& Miller, 2010)

Consumers' perception of fuel economy is almost as important as how they feel about product quality in terms of driving repurchase. These findings show that messages about product quality and fuel economy should be part of communication to existing vehicle owners before they are in market to buy their next car or truck. An increasing number of product messages have centered on fuel economy and efficiency, so our recent findings likely reflect the heightened awareness, and arguably "trained behavior", of new vehicle shoppers to evaluate this attribute. Loyalty is not influenced by communication and marketing alone. The customer experience is also a key driver. Improving the customer experience beginning with the sales process and continuing throughout the customer relationship - will go a

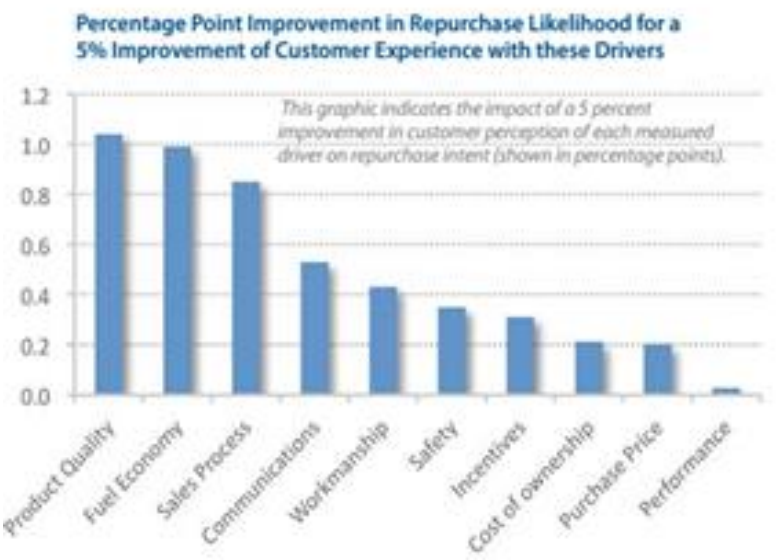

Fig. 6 Impact of measured loyalty drivers Source: (Zetu \& Miller, 2010) long way toward building loyalty. Monetary factors are less important to customer loyalty than many other attributes, indicating that focus on cost savings and deals is not going to lead to higher loyalty of existing customers. Figure 5 shows the relative impact of all measured drivers on repurchase intent, a proxy for loyalty. Manufacturers that sell both luxury and non-luxury vehicles need to understand the differences in what's important to each group of customers. Taking a loyalty strategy that works with nonluxury owners will probably not work with luxury owners based on the results of our analysis. For instance, a company like Toyota may not be able to rely on a "one size fits all" approach and transfer knowledge about what drives loyalty to the Lexus brand to the mainstream Toyota brand.

Percentage Point Improvement in Repurchase Likelihood for a $5 \%$ Improvement of Customer Experience with these Drivers for Luxury and Non-Luxury Owners

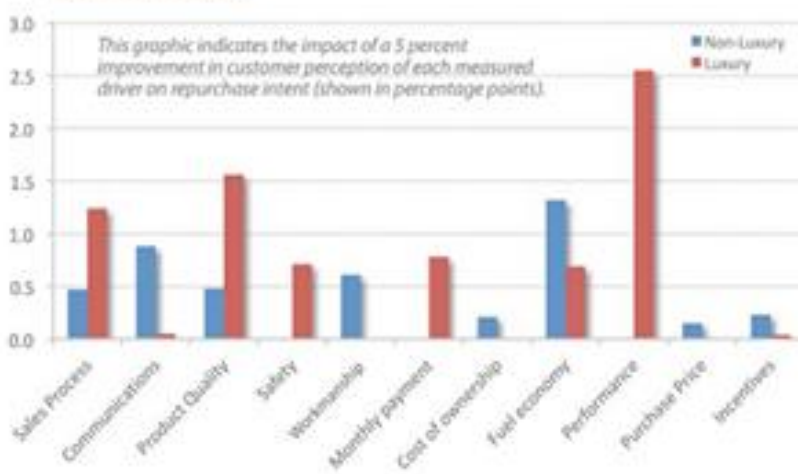

Fig. 7 Key drivers of loyalty for luxury and nonluxury vehicle owners

Source: (Zetu \& Miller, 2010) 
Luxury owners care most about the performance of their vehicles, which makes sense since several luxury vehicles tend to sell based on promises of performance (e.g., for over 30 years, BMW used "The Ultimate Driving Machine" as its core tagline). A 5 percent increase in favorable customer perception of vehicle performance would cause repurchase intent to go up by 2.55 percentage points. Perception of product quality is another key driver of loyalty for luxury vehicle owners, who expect high quality for their investment in a higherend car or truck. These findings show that communication to existing luxury vehicle owners (and to non-luxury owners who might be ready to move up to a luxury vehicle) should include messages about performance and product quality.

Auto manufacturers and dealerships should pay special attention to the sales process for owners of luxury vehicles as it is a significant driver of repurchase. Given the relatively higher pricepoints commanded by premium or luxury brands, these brands need to cater to their unique set of buyers with customer service that's far above average.

Luxury owners have the highest level of loyalty among vehicle segments, regardless of model, brand or corporation. While the average owner loyalty for any given vehicle segment is 37 to 38 percent, 47 percent of returning luxury owners stay with the luxury vehicle segment. In one way, they demonstrate an "I've made it and I'm not moving down" attitude.

In the current competitive market, sometimes building loyalty of existing owners isn't enough. A concurrent area of focus is conquesting. This analysis provides some insights that illustrate how the factors that contribute to repurchase vary by consumer group as defined by the brand origin of their vehicle: USA, Asian and European. Therefore, USA OEMs wanting to conquest current owners of Asian brands, for example, would be wise to understand what is most important to this consumer segment so that they can target them appropriately.

Current owners of Asian brands: As compared to owners of USA and European brands, owners of Asian brands are much more concerned with fuel economy. Therefore, non-Asian OEMs wanting to win over these customers should emphasize this attribute. Interestingly, other factors linked to value are not that important to drivers of Asian brands. Incentives and the monthly payment are two drivers with negligible impact on loyalty.

Additionally, for owners of Asian brands, the customer relationship is of critical importance, as evidenced by the importance that vehicle owners place on both the sales process and ongoing communications. Fuel economy and product quality are the primary driver of loyalty for owners of USA brands. Another product-related quality with a high impact on loyalty is workmanship.

Incentives are a primary driver of repurchase intent, something not seen with either owners of Asian or European brands. Owners of USA brands may have become conditioned to generous incentives because they have been so commonly used by the American manufacturers. One implication is that other brands hoping to conquest current owners of USA brands will need to emphasize pricing and value in order to make these buyers feel they are receiving a great deal.

How managers can dramatically improve their business process and improve to customer loyalty and increase retention using Six Sigma and The Toyota system: eliminating wasted time and process, building quality into workplace systems, finding low-cost but reliable alternatives to expensive new technology and perfecting business processes, all in purpose increasing customer loyalty, customer retention and satisfaction.

\section{WORKS CITED}

Bhote, K. R. (2003). The Power of Ultimate Six Sigma - Keki Bhote's Proven System for Moving Beyond Quality Excellence to Total Business Excellence. Broadway, New York, NY: AMACOM.

George, M. L., Rowlands, D., Price, M., \& Maxey, J. (2005). The Lean Six Sigma Pocket Toolbook: A Quick Reference Guide to Nearly 100 Tools for Improving Process Quality, Speed, and Complexity. New York, NY: Mc Graw-Hill.

Jiju, A. (2007). Winning customer loyalty in an automotive company through Six Sigma: a case study. Quality and Reliability Engineering International, 23(7), 849-866. 
Liker, J., \& Meier, D. (2006). Toyota way fieldbook - A practical guide for implementing Toyota's 4Ps. New York, NY: Mc Graw-Hill.

Zetu, D., \& Miller, L. (2010, Jan). Managing customer loyalty in the auto industry. Retrieved from Blog de Martin Meister: http://www.martinmeister.cl/wp-content/uploads/2013/07/custloyalty.pdf

Received for publication:

Revision received:

Accepted for publication:
24.03.2014

19.10.2015

23.11.2015

\section{How to cite this article?}

Style - APA Sixth Edition:

Popjanev, I. (2016, January 15). Managing customer loyalty in the automotive industry using Six Sigma and "The Toyota way" methodology. (Z. Cekerevac, Ed.) MEST Journal, 4(1), 99-110. doi:10.12709/mest.04.04.01.10

Style - Chicago Sixteenth Edition:

Popjanev, Ilija. 2016. "Managing customer loyalty in the automotive industry using Six Sigma and "The Toyota way" methodology." Edited by Zoran Cekerevac. MEST Journal (MESTE) 4 (1): 99-110. doi:10.12709/mest.04.04.01.10.

Style - GOST Name Sort:

Popjanev Ilija Managing customer loyalty in the automotive industry using Six Sigma and "The Toyota way" methodology [Journal] // MEST Journal / ed. Cekerevac Zoran. - Belgrade-Toronto : MESTE, January 15, 2016. - 1 : Vol. 4. - pp. 99-110.

Style - Harvard Anglia:

Popjanev, I., 2016. Managing customer loyalty in the automotive industry using Six Sigma and "The Toyota way" methodology. MEST Journal, 15 January, 4(1), pp. 99-110.

Style - ISO 690 Numerical Reference:

Managing customer loyalty in the automotive industry using Six Sigma and "The Toyota way" methodology. Popjanev, Ilija. [ed.] Zoran Cekerevac. 1, Belgrade-Toronto : MESTE, January 15, 2016, MEST Journal, Vol. 4, pp. 99-110. 